\title{
Tainted Food and the Icarus Complex: Psychoanalysing Consumer Discontent from Oyster Middens to Oryx and Crake
}

\author{
Hub Zwart
}

Accepted: 9 January 2015/Published online: 29 January 2015

(C) The Author(s) 2015. This article is published with open access at Springerlink.com

\begin{abstract}
In hyper-modern society, food has become a source of endemic discontent. Many food products are seen as 'tainted'; literally, figuratively or both. A psychoanalytic approach, I will argue, may help us to come to terms with our alimentary predicaments. What I envision is a 'depth ethics' (the moral equivalent of a 'depth psychology') focusing on some of the latent tensions, conflicts and ambiguities at work in the current food debate. First, I will outline some promising leads provided by two prominent psychoanalytic authors, namely Sigmund Freud and Jacques Lacan. Subsequently, I will elucidate why our chronic dependency on high-tech food production apparently fails to meet consumer needs, focusing on some scenarios of escape, such as anorexia, cultured meat and ersatz food. And I will use 'genres of the imagination' (novels and art works) to flesh out how food consumption has become a podium for enacting cultural symptoms, moral outcries, provocative identities and practices of the Self. Notably, I will discuss a story by Franz Kafka, a painting by Pablo Picasso and a food novel by Margaret Atwood.
\end{abstract}

Keywords Food ethics - Psychoanalysis - Consumer discontent - Sigmund Freud . Jacques Lacan - Anorexia - Obesity - Margaret Atwood - Oryx and Crake . The Icarus-complex $\cdot$ Cultured meat $\cdot$ Ersatz food

Nobody feels neutral about food (Louise Fresco (2012), Hamburgers in Paradise). For today's ethically-minded consumers, every-day consumption choices can be fraught with anxieties and misgivings (Lucy Atkinson (2013), Clarifying, confusing or crooked?).

H. Zwart $(\bowtie)$

Department of Philosophy and Science Studies, Faculty of Science, Centre for Society and the Life Sciences (CSG), Institute for Science, Innovation and Society (ISIS), University of Nijmegen,

Nijmegen, The Netherlands

e-mail: h.zwart@science.ru.nl 


\section{Introduction}

One of the most baffling paradoxes of affluent hypermodern societies is the extent to which food has become a bone of contention, a source of endemic discontent. The very technologies developed to produce and process high quality food items on a massive scale, offering unprecedented plentitude and abundance instead of hunger and starvation to billions of human earth inhabitants, play a decisive role in this malaise. On the one hand, high expectations are raised and consumers are allegedly enabled to decide for themselves what they will eat and drink at any given time. Indeed, as Korthals (2010) phrases it, all this high-tech tinkering with plants and animals is done to satisfy our desires, cure our health problems, make us happy, "and much more!" (p. 4). At the same time, many of the products so abundantly provided by the contemporary food industry are profoundly tainted one way or another: literally, figuratively or both. Mass media confront us with disconcerting news items on a daily bases: errands about putrefied food products, livestock pandemics, conflicts over genetic modification, animal suffering, environmental pressures or gruesome labour circumstances, in short: 'consumer concerns'. Various unhealthy (or even life-threatening) conditions related to problematic food habits, such as alcohol abuse, obesity and anorexia, have assumed epidemic proportions in contemporary Western societies. And still, we seem unable to produce enough, so that millions of people worldwide are suffering from malnutrition. What is wrong with our food? Why is our relationship with food beset with challenges, anxieties and ambiguities? Why are we unable to produce the food we really desire?

A psychoanalytic approach, I will argue, can help us to probe these issues. What I envision is a 'depth ethics' (the moral equivalent of a 'depth psychology') focussing on some of the latent tensions, conflicts and ambiguities at work in the current food debate. During the first decades of the twentieth century, when psychoanalysis came of age, the focus was on sexuality as a key factor in determining who we are and what we aspire. In the contemporary world, food has assumed a similar position. For numerous consumers, the consumption of fast, slow, halal, kosher, green, vegetarian, fair trade or genetically modified food products has become part of their identity. Food choices allow us to take position in some of the major societal debates and collisions of today.

First, I will outline some promising leads provided by two prominent psychoanalytic authors, namely Sigmund Freud and Jacques Lacan. Subsequently, I will elucidate why our chronic dependency on high-tech food production apparently fails to meet consumer needs, focussing on scenarios of escape, such as anorexia, cultured meat and ersatz food. And I will use 'genres of the imagination' (novels and art works) to flesh out how food consumption has become a podium for enacting cultural symptoms, moral outcries, provocative identities and practices of the Self. Notably, I will discuss a story by Kafka, a painting by Picasso and a novel by Atwood. 


\section{We are What We Refuse to Eat: Some Freudian Leads}

Freud already pays attention to food intake in his some of his earliest case histories, describing repugnance towards food ${ }^{1}$ in young, 'hysterical' patients. One of them ('Frau Emmy v. N.'), is portrayed as an “ascetic medieval monk" (1895/1952, p. 119). From the very outset, however, attention to alimentary inhibitions is eclipsed by Freud's abundant interest in sexual predicaments.

His interest in food becomes more outspoken, however, in the context of his fascination with Totemism (1913/1940), notably totemic meals and dietary rules resulting from them. Once upon a time, Freud argues, Totemism gave rise to the idea that particular food products or food ingredients are contaminated in a symbolical way. They became associated with the (cannibalistic) totem meal, and their inadmissibility is actually a by-product of the categorical rejection of cannibalism, the first commandment of human culture (as ancient as, and closely connected to, the prohibition of incest/the oedipal complex). By refusing to consume such products, individuals constitute themselves as moral subjects, defining and emphasising their identity (in terms of kinship, ethnicity, religion, or otherwise) with the help of food. In other words: from a totemic perspective, individuals basically are what they do not eat, what they refuse to eat. For Freud, modern human beings can still be seen as 'totemic' in the sense that, consciously or unconsciously, the logic of Totemism remains part of their inherited relationship towards food. To paraphrase Ludwig Feuerbach's famous quote: "Der Mensch ist, was er nicht isst". Various phenomena connected with prehistoric Totemism are echoed (repeated) by modern neurotic individuals suffering from an excessive ('irrational') fear of contamination, who desperately try to keep their hands, bodies and conscience clean. Yet, again, in his further elaboration of contemporary (atavistic) 'Totemism' (neurosis), Freud focused on psychic obstacles that have a detrimental effect on intimacy and love, rather than on food intake.

A final Freudian document which seems especially apt to shed light on contemporary consumer concerns and food issues is Das Unbehagen in der Kultur ('Civilisation and its discontents', Freud 1930/1948). Here, the question is raised why human beings, living in affluent and highly advanced societies (apparently designed to enable us to satisfy all our needs, up to the point of spoiling us), continue to feel dissatisfied and unhappy. Why all this suffering in a world of unprecedented abundance (historically speaking)? What can be done about it?

Freud lists a number of strategies that have been deployed to counteract discontent and promote happiness (or at least to reduce unhappiness). One method, Freud argues, has been the development of science and technology, allowing us to control and subdue nature. Human societies have made undeniable progress in this respect: the soil has been cultivated and planted, animals have been domesticated, and we ourselves have become 'prosthesis-gods', equipped with various contrivances (like artificial limbs). But this has not made us happy, if only because these self-made auxiliary organs, and the various forms of labour connected with them, tend to become sources of uneasiness in their own right.

\footnotetext{
1 “Abscheu vor der Speise” (1892/1952, p. 11); “Abneigung gegen Speisen” (1905/1942, p. 187).
} 
Another method is intoxication, the use of substances to temporarily evoke pleasurable sensations, but these often result in addictions and other health problems, so that in the end consumers are worse off.

The same applies to the method of the hermit, who breaks off all connections with society and retreats into an ascetic private world. Instead of experiencing happiness, such individuals are often plagued by desire and a chronic sense of guilt. In the Far East, annihilation of desire has been aspired, by Yogi and others, but according to Freud, although this may (perhaps) lead to a reduction of unhappiness, it will not give us happiness as such.

Some seek solace in erotic love, hoping that, by indulging in uninhibited Dionysian pleasure, our cravings can be satisfied, but Freud reminds us that wise men of all ages have warned emphatically against this way out, arguing that to give in to erotic desire is dangerous. In fact, according to Freud, the sexual life of modern humans has become seriously disabled.

Another method is sublimation: the gratification of desire through art (creating things of beauty), or through scholarship and research (the discovery of truth), but this is only attainable for a limited number of people, who continue the feel unhappy (the 'unhappy few' as it were) and for whom life often becomes a source of suffering and sacrifice rather than of pleasure.

Instead of creating art ourselves, we may of course enjoy its products, and indeed: things of beauty may function as a 'mild narcotic', as Freud aptly phrases it, but they only grant us a temporary refuge.

As a final way out, Freud mentions the flight into neurosis, the retreat into a private phantasy-world, offering substitute-gratifications, but also giving rise to various symptoms, causing severe unhappiness and isolation in the long run, hampering intimate relationships as well as professional careers.

In short, all methods that have been tried so far have faltered. Civilization itself seems to blame, because although we have become increasingly dependent upon our socio-technical environment for survival, it actually often hinders us to attain the goals we really consider worthwhile. And this deadlock results in chronic uneasiness, so that we seem unable to improve our situation.

To make matters even worse, the pleasure principle (the striving for happiness) is not the only 'program' of human life. It is complemented by a tendency towards (self-) destruction, the so-called death drive: an additional obstacle on the road to happiness. Instead of allowing us to satisfy our aggression, cultural environments force us to internalise it, turning it against ourselves in the form of a chronic sense of guilt. Our conscience or super-ego is exceptionally harsh, especially in the case of apparently virtuous human beings. Thus, civilisation tends to increase our (unconscious) desire for punishment, notably when happiness suddenly seems to be within our reach.

Freud does not explicitly mention food consumption as a method of fostering human satisfaction. The various forms of pleasure involved in growing, producing, processing and enjoying food are not explicitly discussed. Overall, the 'oral' dimension of human existence is not very elaborately developed in Freud's oeuvre. And yet, it is clear that, if seen from a Freudian perspective, food consumption (as a method to boost human happiness) entails significant problems of its own. For 
various reasons, the supermarkets of today are sources of uneasiness rather than of pleasure. Quite often, we feel like Alice in Wonderland, faced with a plethora of edible and inciting EAT ME, DRINK ME items. Yet, if we give in to these provocative invitations, unpleasant by-effects may occur, ranging from allergic reactions up to weight gain, hang-overs, addictions, caries, obesity and diabetes. And quite often it results in unsustainable life-styles.

From the point of view of present-day science, moreover, it could be added that, although, since the Neolithic revolution, agriculture (the original meaning of cultura) has saved us from starvation, it also introduced a split or gap, a basic tension into our lives, namely between our (slowly evolving) Palaeolithic genome and our Neolithic (or even post-Neolithic, modern) diet (Zwart and Penders 2011). Thus, a mismatch developed between 'nature' and 'nurture', between our genomes and our food intake, so that various food problems, ranging from obesity up to gluten intolerance or allergies can be traced back to this basic split. This same mismatch may also explain (to some extent at least) the seductiveness of pastoral phantasies, notably in a hypermodern, technological environment, leading to a quest for 'natural' food-but we will come to that.

\section{Jacques Lacan, the Irretrievable Oral Object $a$}

Building on Freud's ideas on what causes chronic human discontent, Jacques Lacan likewise contends that an insurmountable gap has developed between what we seek and what we actually find in this world. Human beings are basically Mängelwesen, Lacan argues, lacking something which (other) animals have: a natural attunement, a 'pre-established harmony' between body and environment. Therefore, we are confronted with an unsettling situation involving a craving, desiring, split, 'divided' subject (in Lacanian grammar: \$) who is desperately looking for something, the 'object $a$ ', i.e. the alluring but absent object of desire which remains beyond our reach. No type of food will ever satisfy our oral drive, except this inexorable, phantasmatic object which seems perpetually missing. ${ }^{2}$ Thus, the human condition is expressed by Lacan with the help of the 'matheme of desire': $\$ \diamond a$.

Although Lacan (like Freud) predominantly focussed on sexual desire to develop his ideas, this scheme may also be employed to probe our problematic relationship with food (the 'oral' dimension of human existence). From a Lacanian perspective, whereas no available food product seems able to satisfy our craving, we nonetheless continue to yearn and search for it.

This is closely connected with Lacan's concept of the 'symbolical order'. From a purely physiological perspective, contemporary food items seem perfectly able to satisfy our daily bodily needs, but human consumers do not live on bread alone, as the Bible phrases it (Matthew 4:4). Quite the contrary: we live primarily on words. First of all, in the case of modern humans, edible items are not ready-at-hand, but mediated by the 'symbolical order' (the realm of language, discourse and

\footnotetext{
2 “Aucune nourriture ne satisfera jamais la pulsion orale, si ce n'est à contourner l'objet éternellement manquant" (1973, p. 201/202).
} 
regulations). A gap has arisen between production and consumption, and this gap is infiltrated by 'symbolical' items ('signifiers'), such as: product information, dietary advice, cultural prohibitions, health claims, safety regulations, brand names, logos, eco-labels, and so on. Thus, the market has become a discursive arena, and as a consequence of that a place of desire, of uncertainty and anxiety (Schroeder 2004). From a Lacanian perspective, a supermarket is not simply a collection of edible entities, but first and foremost a diorama densely filled with signifiers. Organizations such as the United States Food and Drug Agency, moreover, responsible for protecting and promoting public health through regulation and supervision, emerge as authoritative (fatherly) figures allowing us to distinguish what is admissible from what is inadmissible. And through our (usually quite repetitive) dietary choices, we signal implicit consumer compliance or consent, so that the symbolic order is constantly reinforced.

Moreover, the symbolic order entails the claim that the contemporary food market in principle allows consumers to satisfy all their needs. And yet, discontent arises from the (unconscious) conviction that, somehow, the one item that really gratifies our tormented desire is not included in what is so abundantly supplied. Until, all of a sudden, it seems to present itself to us in all its glamour, as an irresistible alimentary trouvaille or lucky strike-think for instance of the famous Madeleine cake-scene in Proust's novel Remembrance of Lost Time, bringing back forgotten, nostalgic childhood memories associated with particular food items. As soon as the crumbs of the cake touch the narrator's palate, a shudder runs through him, and an exquisite pleasure invades his senses, a sensation comparable to falling in love, filling him with a precious essence, so that all of a sudden the vanished, precious memory resurges. Experiences like that often tend to be transitory, however, and questionable. Did it really taste the same? Will it really gratify his cravings? And images on cake packaging evoking childhood memories will doubtlessly raise suspicion among critical consumers.

This singular dynamics of human desire also helps to explain our interest in food products that purport to be as 'natural' as possible, building on the nostalgic conjecture that once upon a time, a much more harmonious and gratifying situation must have existed (Zwart 2009), an idea which resonates with the time-old yearning for the land of Cockaigne, when the Venus of Willendorf was still venerated, an almost mythical world of primordial, Paleolithic diets, when food was still "true and honest" (Fresco 2012), an epoch sometimes associated with the golden era of affluent hunter-gatherer societies (Sahlins 1968, 1972). For Lacan, this pastoral longing, promising release from our current malaise in the form of a 'return to nature', is an inevitable but illusory by-product of modern civilization. ${ }^{3}$

In contemporary society, the most prototypical exemplification of the idea of a purely natural (and therefore untainted) food item appears to be the oyster: a consumable which apparently approaches our oral 'object $a$ ' as closely as practically possible. Fernández-Armesto (2002) published a comprehensive history of food entitled Near a Thousand Tables, the first chapter of which is dedicated to

\footnotetext{
3 "La dimension de la pastorale n'est jamais absente de la civilisation, et ne manque jamais de s'offrir comme un recours à son malaise" (Lacan 1986, p. 107).
} 
the 'oyster experience'. Eating oysters, he argues, is a step back into food history (comparable to some extent with Proust's Madeleine-experience). Oysters constitute the nearest thing we have to 'natural food', uniting us with our distant ancestors. There is no food in modern Western cuisine as convincingly natural as this, he claims. While eating it, we are thrown back into a pre-civilized world, an almost pre-human phase of evolution.

Lacan is likewise interested in oysters, and similar forms of shell fish, such as mussels and clams. From the very outset, however, he emphasizes that such consumables, as soon as they are touched by human hands, are bound to enter the symbolical world of culture. Not only because nowadays oysters are usually eaten in trendy restaurants, but also because heaps of shells and other debris, collected by prehistoric consumers, nowadays constitute an important target for archaeological research. Such heaps are known as 'middens' or (with a Danish term) as kjökkenmödding (Lacan 1965/1966). They are more than just waste: they were construed on purpose, as primordial pyramids, functioning as markers in early human landscapes, or 'foodscapes', indicating: this is our place, our site, but perhaps also as tokens of Palaeolithic affluence, or of boredom. To us, they are helpful as time capsules, constituting valuable archives for research. In Lacanian terms: these middens were signifiers, carriers of a message. Thus, even our most elementary nutritional needs became embedded in a symbolic order (1981, p. 223). Even for pre-historic humans, the oyster was never purely natural. A symbolical, cultural dimension was associated with it from the very outset.

Another example of a food item that purports to be 'untainted' is the wafer, figuring in Holy Mass: a kind of 'minimal food' product, allegedly gratifying higher needs, consecrated, purified and clean, a gift from above (manna), involving a minimum of waste, an entity which mimics the salvaging, highly valuable object $a$ as closely as possible. At the same time, it has always been a bone of contention, even to the highest extreme. Besides accusations of cannibalism during the early Christian era ("This is my body", Luke 22:19), religious Wars, involving incredible death tolls, have been fought over this tiny, almost weightless entity, to settle hefty early modern theological disputes concerning its ungraspable 'true' nature. In general, edible entities which promise salvation should put us on guard. Remember that gift (in English) means poison (Gift in German) as well, which is of course the basic morale of the Snow white fairy tale, as well as of the biblical story of Eve and the apple.

\section{The Object $a$ and High-Tech Food}

The concept of the 'object $a$ ' may also be associated with the very opposite of 'natural' food, namely high-tech food. One interesting example of this is cultured meat (also known as vegetarian meat, 'in vitro meat' or test-tube burgers), made from algae, or from stem cells (taken from pigs for instance), or from other forms of 'carniculture'. Here is a food product with the aura of being untainted, promising a significant reduction in both animal suffering and the emission of greenhouse gasses (Hopkins and Dacey 2008; van der Weele and Driessen 2013; van der Weele and Tramper 2014). At the same time, it seems profoundly tainted in the sense that it is 
extremely unnatural, so that it will even further alienate us from our natural food (van der Weele and Tramper 2014, p. 294).

For entities such as cultured meat, psychoanalysis has coined a special term, namely: 'the uncanny' (Freud 1919/1947). The uncanny is not simply the unnatural; it is something much more paradoxical than that. The term refers to entities that seem natural (organic, authentic) without being it, entities that have become disconnected from their original context, have suffered a drastic metaphysical change: looking and tasting (to a certain extent) like meat, but growing like a mushroom or a plant. Thus, it has become a highly ambiguous and contested food product, representing the intermediary zone between dangerous and beneficial, real and unreal (Hopkins and Dacey 2008, p. 586). It may even become a bio-object mid-way between science and art, as in the "disembodied cuisine" or "victimless meat" experiments performed by bioartist Oron Catts (van der Weele and Driessen 2013, p. 649).

One argument against in vitro meat, listed by Hopkins and Dacey (2008) is that, one way or another, the connection with animals will always be there, for instance because animals will act as stem cell or tissue donors, or because in vitro meat will continue to look like animal meat. Therefore, in the eyes of sceptics or critics, it will continue to be morally "suspect" or even "tainted" (p. 591). One way or another, a "moral taint" will always be present, as a secularised version of the (ineradicable) original sin.

Another possible candidate to count as untainted food is space food: an almost unearthly, highly artificial, high-protein, low-residue consumable, developed to minimize weight, waste, bowel movements and digestion; the astronauts' version of a wafer. In other words: cleansed, 'pure' food, but at the same time utterly detached from its earthly, organic origins.

During recent decades, biotechnology has produced countless food products that purport to be high-tech manna, providing us with the very thing we lack. An intriguing example of this is Golden Rice of course, allegedly the perfect answer to nutritional and health problems for millions of people. Ironically, it has become a 'tainted' food product par excellence, associated with high-tech manipulation of crops and profit-seeking multinationals such as Monsanto. From a Lacanian perspective, all this is fairly predictable. Any food product which is presented as (the perfect substitute of) the oral object $a$, is bound to raise controversy and suspicion. Thus, genetically modified crops (entities developed to confer benefit on humankind) came to be regarded as 'tainted' and uncanny, entailing dangerous potentials for environmental pollution and economic disruption. Countless regulatory initiatives have been taken to contain dispersion, moving in the direction of a collective neurosis at times. What is it that taints these types of food, turning allegedly wholesome and beneficial consumables into something downright uncanny? To understand this dialectic, it is helpful to reflect more extensively on the recent history of industrialised food products and their symbolic surplus value.

\section{Canned Meat and the Uncanny}

The modern food industry is often presented as a paradigmatic exemplification of human technological power over nature. In his novel The Jungle (1905/1906) Upton 
Sinclair paints a rather depressing picture of the Chicago meat industry around 1900, with 'rivers of life' (cattle arriving day after day from the American plains in large numbers) being transformed, in a highly efficient manner, into canned meat, thus producing affordable meat products and protein-containing diets for the masses, the working-class consumers in booming American cities. Millions of live creatures were turned into food on a daily basis (p. 37). The stream of animals was continuous, Sinclair tells us: river of hogs would be brought in to be processed into canned meat in an insensitive, machine-like, assembly-line fashion: pork-making by applied mathematics (p. 40). Thus, canned meat became the emblem of "ontological violence" inflicted on animals (Zwart 2014).

Canned meat represents market value as well as nutritional value, providing human city-dwellers with a reliable source of protein. At the same time, it is highly uncanny, a symptom of the unsettling technological power of human beings over life. Canned meat is tainted food par excellence, exemplifying the extent to which the pastoral proximity of humans and animals (in the context of the agricultural village of former times) has given way to an unsurmountable ontological divide, between animals and humans (who have become estranged from one another), but also between production and consumption, as well as between households and machines. The meat factory is a prototypical black box, so that the violence done to animals is normally hidden from view; in psychoanalytic terms: 'repressed'. It is no longer embedded in everyday life. But uneasiness and moral repugnance will not go away. Instead, the repressed dimension (violence to animals) is bound to return at the other end of the food chain, in the form of 'consumer concerns', of which Sinclair was a pioneer protagonist.

But, topologically speaking, there are two sides to a tin can. On the one hand, the inner content contained by it is hidden from view (repressed). Its 'animality' is processed and subdued, often beyond recognition. At the same time, tin cans (or other forms of packaging) enable practices of labelling, thus opening up an important arena for the symbolical and the imaginary. Cans are containers of food, but also carriers of messages and information. They communicate with and actively address the outside world ('eat me!', 'drink me!', 'I am wholesome and clean!'). In Lacanian terms: whereas the 'real' thing (meat as something we may see, touch or smell) is hidden from view, it is replaced by 'symbolical' information, by 'signifiers': by acronyms, abbreviations and technical terms, such as omega-3 fat, antioxidants, thiamine (Vitamin $\mathrm{B}_{1}$ ), folic acid etc., or by various standardized symbols (such as e-codes), but first and foremost by numbers: quantitative information concerning weight, shelf life, calories, ingredients, etc.

In fact, when it comes to contemporary food items, three dimensions can be distinguished: (a) the 'real' (the actual content, in most cases highly processed and hidden from view, as we have seen); (b) the 'imaginary' (for instance: alluring pastoral or nostalgic images of traditional food production and consumption, meant to 'greenwash' what quite often are assembly-line products; or images of athletic, healthy, beaming consumers); and (c) the 'symbolical' (factual information, preferably presented in standardized formats, including quality marks, barcodes, best before dates and the like). Thus, food labels signify the enormous distance that has arisen between production and consumption, as an inherent essential 
characteristic of the hypermodern global food system (Zwart 2000, 2005). At the same time, they act as intermediaries aimed at diminishing this gap. In malls and supermarkets, the loss of authenticity and intimacy (in the form of visible, tangible, smelly food, such as can still be encountered by tourists in open air meat, tripe or fish markets, for example) is compensated by the presence of (painstakingly regulated) labels, representing the 'symbolical order', safeguarded by authoritative institutions such as the FDA, combined with various seductive 'images' (representing the 'imaginary').

Modern consumers may well experience a sense of disappointment, however, whenever the canned (or otherwise wrapped up) food content is brought out into the open. The basic tension between inside and outside, between content and label is always there. There is always the lingering (perhaps unconscious) hope on the part of the consumer that there must be more to food than what is captured by the dense symbolical information (complemented by concise imaginary phantasmagorias of pleasure and youth) forwarded by the label.

This is not exclusively typical for food products, of course. The 'symbolisation' of the real (i.e. the systematic replacement of tangible and visible 'things' by standardized information, and of 'materiality' by 'data') is a basic tendency of modern civilization as such. In many cases, the label or brand (in the case of wine or whiskey for example) will perhaps be more important than the materiality itself. Thus, the real thing is literally obliterated by the letters, the brand, the logo (the ' $\lambda$ ó $\gamma \circ \varsigma$ ' of a commercialized society), by numbers and other 'signifiers'. Although this is a general and, up to a certain point, inevitable tendency, in the world of food products it is perhaps more noticeable than elsewhere.

\section{The Obliteration of Icarus}

In 1957, Pablo Picasso painted a mural for UNESCO headquarters in Paris: a sizable art-work (almost hundred square meters) known as The Fall of Icarus, portraying fleshy, bathing figures as bystanders silently witnessing the downfall of a fragile, fleshless, disembodied, Icarus-like human who seems to have lost all materiality, who seems X-rayed, obliterated and transformed into a pale, frail and weightless anorectic: not as a psychiatric condition (an 'eating disorder'), but rather as a cultural minimum: the idea of weight minimalisation taken to its extreme: a human being stripped of its animality, its flesh.

In a classical study Selvini-Palozzoli (1985) has argued that anorexia is a syndrome pertaining to affluent societies, befalling human beings in situations of over-abundance, embodying a silent outcry, a gesture of tacit protest. Although it is basically a (life-threatening, even fatal) condition, it is enveloped in a moral aura. To the extent that it is a moral outcry, the question may be raised: against what?

First of all, we must realise that, paradoxically, contemporary culture is at the same time afflicted by another life-threatening syndrome, a mirror condition as it were: namely the obesity pandemic. Unlike anorexia, obesity is usually associated with the 'lower classes'; i.e. individuals of lower socioeconomic status (SES). Indeed, its socio-cultural dimension should not be ignored. Since time immemorial, 
slenderness has been an elitist ideal, a bodily practice which allowed individuals of the higher strata to distance themselves from the folkish (rural) masses. For the latter, stoutness/portliness has always been a positive ideal, exemplified by popular heroes such as Gargantua and Pantagruel, whose weightiness was associated with vigour, fecundity and health. Anti-obesity campaigns often focus on quantitative information in terms of health risks, while ignoring the tenacious cultural dimension (obesity as a form of subcultural 'resistance' against elite ideals).

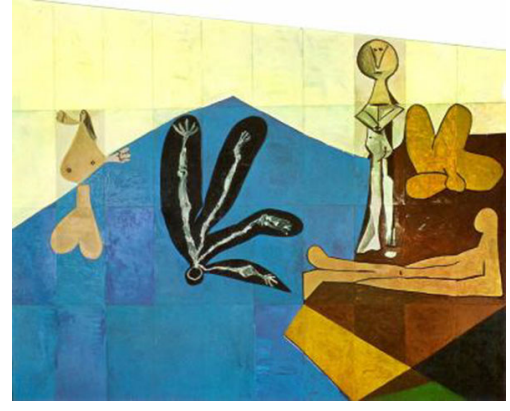

Anorexia as a cultural phenomenon has a different meaning, taking the slenderness ideal to the point of extreme. As Lacan points out, the anorectic patient literally eats nothing. ${ }^{4}$ Rather than not eating, anorexia signifies eating nothing. ${ }^{5}$ It is an act of self-obliteration in the literal sense of the term. The anorectic body blots itself out, evoking a voiceless protest against unfulfilled desire: a body assuming the shape of a living character. The anorectic cannot find the food he/she really desires. Untainted, gratifying food (the object $a$ ) is emphatically absent. From a Lacanian perspective, anorectics do want to eat, but the object $a$ (or a credible substitute for it) is missing. Anorectics therefore consume themselves: they are consumed, as it were, by their food deprivation, subjecting their body to a process of de-carnation or disembodiment. A body is stripped to its bare essence. Notably secondary sex characteristics (involving flesh, fat and muscle tissue) will disappear, so that it becomes increasingly difficult to distinguish male anorectics from female ones. This is aptly captured by the phrase 'mannequin', which literally means tiny, fragile man. Anorectics are plagued by a sense of guilt. There consistently seems to be too much of them. They strive for self-obliteration, as a gesture of oral protest.

This is immortalized by Kafka's famous story of the Hunger Artist, who breaks all records in professional fasting, transfiguring himself into a living skeleton (as in Picasso's mural). And still, he is haunted by a relentless sense of guilt. "Forgive me", he says, when, towards the end of the story, they coincidentally discover his shriveled body on the floor of the cage, "but do not admire me. I fasted because I could not help it":

"What a fellow you are," said the overseer, "and why can't you help it?"

"Because," said the hunger artist, lifting his head a little and speaking, with

\footnotetext{
4 “Dans l'anorexie mentale, ce que l'enfant mange, c'est le rien", 1973, p. 11.

5 “L'anorexie mentale n'est pas un ne pas manger, mais un ne rien manger. J'insiste-cela veut dire manger rien ... Ce n'est pas un nicht essen, c'est un nichts essen (1994, p. 184/185).
} 
his lips pursed, as if for a kiss, right into the overseer's ear, so that no syllable might be lost, "because I couldn't find the food I liked".

He was not an insensitive person, far from it: he was tormented by desire, but failed to find his object $a$, and persisted in his refusal to go for tainted food instead. Had he found something really edible, he surely would have "stuffed" himself, as he phrases it, like everybody else. But he refuses to oblige to the reality principle, insofar as food is concerned.

Thus, anorexia (as a cultural ideal, but also as a psychiatric syndrome) can be regarded as a form of acting out, as the enactment (on an alimentary podium) of a voiceless protest against affluent, hypermodern, metropolitan societies of today, whose consumable food abundance fails to gratify our true desire. Our sociotechnological environment has assumed metropolitan proportions. Remember that metro-polis literally means mother-city. The somatising protest seems to be directed against a super-motherly production system bent on spoiling us with consumable, edible products, surrogacies of the real 'thing', failing to provide us with the one enigmatic something we really crave for. Anorexia is a kind of 'negative addiction' as it were; addicted to eating nothing.

Although most anorectics are female, the condition does occur in males. In recent years, a number of male mannequins, almost indistinguishable from their female congeners, have successfully taken up catwalk modelling in female attire. Andrej Pejic, Stav Strashko and Stas Fedyanin are among the most well-known examples. Anorexia (excessive weight loss) is the route to take in order to achieve this goal. Pictures of Stav Strashko for instance (easily downloadable from the internet) indicate that, although 'gender bending' (gender obfuscation) may be a motive for this type of body art (the 'phallic' dimension), something else seems to be at stake as well, namely self-obliteration. Below a certain weight limit, human individuals (male or female) achieve a featherweight condition, while sex differences become obfuscated, almost to the point of obliteration. It is an enactment of the Icaruscomplex, rendering a human body as fragile as an X-ray picture.

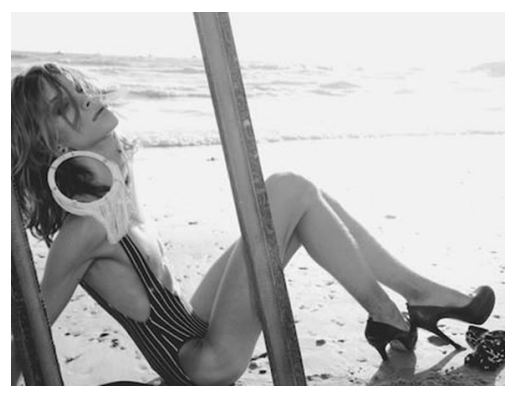

Strashko seems to suffer from dehydration: a mermaid stranded in a desert, a human being who apparently came too close to the sun, and subsequently lost something, his wings no doubt, falling downwards, although instead of disappearing into the waves, a displacement has occurred: he has landed in an 'ocean of sand'. Daedalus (the father-figure, the food bio-engineer) developed the biotechnologies that allowed young Icarus to flourish and survive, but instead of using these precious 
consumables with moderation, he went into extremes. In a world of technically reproducible abundance, it seems difficult to steer a middle course, between overconsumption and under-nourishment. The anorectic subject fails to find the proper (untainted) food to eat. While dehydrating and obliterating himself, the tormented subject apparently experiences a painful kind of pleasure, a forbidden joy, referred to by Lacan as 'jouissance': an exquisite pain, an ecstatic moment of too much pleasure, induced by eating nothing.

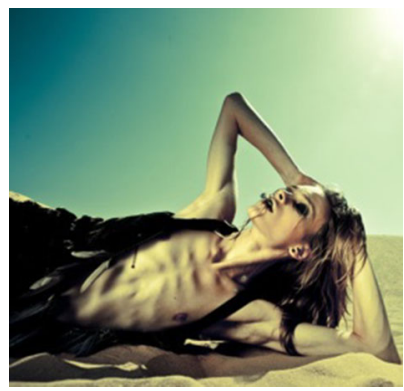

Rather starve yourself than accept to be tainted. In Hegelian terms, the cultural anorectic represents the position of the unhappy "beautiful soul", unable to cope with a profound experience of loss, about to obliterate himself, "vanishing like a shapeless vapour" 6

The question now is: is there a way out? Anorexia ultimately amounts to a lifethreatening condition rather than a viable moral solution. Although losing weight as such may seem perfectly in order, this should not be taken to extremes (as in the Icarus-case). Anorexia is a 'negative excess': the anorectic as a hypermodern Midas, turning everything he touches into gold, into an inedible (impossible) object, eventually dying from starvation.

One possibility is that the hypermodern food industry will provide us with an answer. That which causes our alienation in the first place may now be called upon to help us out. In our search for the oral object $a$, we may perhaps put our bets on new generations of 'untainted' food products coming from the bio-industry, so that the anticonsumerist beautiful soul, bordering on anorexia, and transmuting objects of pleasure into objects of disgust (Morton 2007), may be reconciled with cultured food. In the final section, I will briefly analyse a novel which purports to record the vicissitudes of a culture bent on replacing unsustainable food products by biotech surrogacies.

\section{Bioperversity: The Brave New Foodscape of Oryx and Crake}

Margaret Atwood's Oryx and Crake (2003) is first and foremost a food novel. The narrative alternates between two near futures: a pre-apocalyptic and a post-

\footnotetext{
6 "Sein Tun ist das Sehnen, das in dem Werden seiner selbst zum wesenlosen Gegenstande sich nur verliert und, über diesen Verlust hinaus und zurück zu sich fallend, sich nur als Verlorenes findet; in dieser durchsichtigen Reinheit seiner Momente eine unglückliche sogenannte schöne Seele, verglimmt sie in sich und schwindet als ein gestaltloser Dunst, der sich in Luft auflöst” (Hegel 1807/1970/1986, p. 484).
} 
apocalyptic world, before and after a cataclysmic event (the outbreak of a lethal, bio-engineered viral pandemic). While the pre-apocalyptic world is a prolific producer of ersatz food products (notably cultured meat and other types of surrogacies), the post-apocalyptic world is inhabited by survivors fighting off starvation, in the aftermath of the sudden meltdown of man-made technologies and food-providing infrastructures. After Daedalus (the bio-engineer of artificial food products) comes a fallen, post-consumerist Icarus, dwelling on a beach. For various reasons, Atwood's novel mirrors (or rather: amplifies) important present-day concerns about food, projecting them into the arena of the future.

Jimmy, the novel's protagonist, who now calls himself Snowman, inhabits a near-future world disrupted by climate change, bio-manipulation and extinction. He is (as far as we can tell) the sole human survivor of a global pandemic, bioengineered by his former classmate, a mad genius named Crake. Snowman dwells on a beach littered by post-apocalyptic debris, meanwhile keeping an eye on a herd of genetically altered humanoid vegetarians: the "Crakers", noble savages fabricated to replace humankind. Whereas most of the current species have disappeared, the sultry landscape is roamed by man-made chimeric 'bioforms', such as green luminescent rabbits, 'rakunks', 'wolvogs' and 'pigoons'. The latter, officially known as sus multiorganifer, are a genetically modified ('spliced') variety of pigs, brought into the world for xenotransplantation. A man-made airborne haemorrhagic virus has deliberately wiped out humankind, because (in the eyes of Crake) our species had become an ecological disaster.

The two futures entail different topologies. The pre-apocalyptic landscape had been dominated by two types of place, namely Compounds and pleeblands. Compounds were fortress-like, luxurious enclaves, heavily gated and frantically policed, surrounded by ramparts and watchtowers to enforce a cordon sanitaire. Here, the elites (notably scientists involved in commercial bio-engineering projects) sought shelter from social disruption and bio-attacks coming from outside. Bio-safety and immunisation were key concerns. The rest of humanity was relegated to the pleeblands: anarchic places, dangerous and polluted, depicted as giant "petri dishes" containing contagious plasma (p. 287), ${ }^{7}$ but also used as testing grounds/outdoors laboratories for biotechnological and pharmaceutical experiments (Cooke 2006, p. 68). With its high-tech food products, computer games and sordid internet sexuality, Oryx and Crake depicts a preapocalyptic future society that "only slightly exaggerates ... worrisome trends that are already rampant" in the early twenty-first century (Hall 2009, p. 179; Cf. Snyder 2011; Hambuch 2013). ${ }^{8}$ Indeed, the novel amply draws from current headlines about environmental crises and genetic engineering, in combination with bioterrorism and sex trafficking.

\footnotetext{
7 "If you grew up surrounded by it you were more or less immune, unless a new bioform came raging through; but if you were from the Compounds, you were a feast. It was like having a big sign on your forehead that said, Eat Me" (p. 287).

8 Atwood's "dystopian speculative fiction takes what already exists and makes an imaginative leap into the future, following current sociocultural, political, or scientific developments to their potentially devastating conclusions", thus inciting us to see the future in the actual present (Snyder 2011, p. 470).
} 
Jimmy grows up in the Compounds: the realm of ersatz food products. Among the products mentioned are soy-sausage dogs; SoyOBoyburgers, SoYummie Ice Cream, chocolate soy, mango soy, chocolate soy goo, microwaved dinners, butter substitute, CrustaeSoy, ChickieNobs Nubbins, soyboys, joltbars, soyafries, soytoast and SoyOBoy sardines. Despite the proliferation of fast food items and electronic gadgets, human beings are profoundly unhappy and dissatisfied.

The post-apocalyptic world, on the other hand, is a devastated landscape, littered by the rubble and trashes of the pre-apocalyptic civilisation that has now vanished. It is inhabited, as far as we can tell, by only one human survivor, Jimmy/Snowman, the last of Homo sapiens, for whom the near-future is already a traumatic memory. He spends his time scavenging and foraging a devastated world, looking for something edible amidst the litter and waste. Suffering from sunburn, haunted by traumatic memories and unable to adapt, he is "marooned in time, cast away between a human past and a post-human future... a post-apocalyptic atavism" (Snyder 2011, p. 472). Jimmy/Snowman acts as a kind of archaeologist of the recent past (our nearby future). He seems well equipped to do so, moreover, as he was actively involved in bringing about the catastrophe (as a former insider, serving as Crake's right-hand man).

A key term in Atwood's novel is ersatz. Pre-apocalyptic society is a prolific producer of surrogacies of every kind, notably in the area of food. During his scavenging forays, Jimmy comes across cans of Sveltana No-Meat Cocktail Sausages, chocolate-flavoured energy bars and ChickieNobs Bucket O'Nubbins (p. 4). The latter actually consists of cultured meat. These items are not a pleasure to eat. After having consumed a chocolate energy joltbar, for instance, Snowman opens a can of Sveltana No-Meat cocktail Sausages, "a diet brand, unpleasantly soft. But he manages to get them down. Sveltanas are always better if you don't look" (p. 149).

With empty bottles, cans and containers, he builds a midden-heap (p. 152), his own private dump: the leavings of catastrophe, symbolising his return to the first chapter in the history of human food, as we have seen: the midden as a token of human presence (acting as a signifier): this is my dwelling, my identity, my life.

Jimmy no longer represents the top of the food chain, moreover. New types of animals such as wolvogs and pigoons consider him as protein source. His helplessness is symptomatic of humanity's complete reliance on technological infrastructures and institutionalized food production. Snowman's fixation on food results from his utter inability to provision himself. Without supermarkets, magnetrons and refrigerators he seems utterly lost, lacking even such basic survival skills as identifying edible plants or invertebrates (Galbreath 2010).

One of the new bioforms dwelling on the beach is a new variety of anthropomorphic beings called 'Crakers' (or 'Children of Crake'), genetically engineered human-like creatures: floor-models meant as an alternative to contemporary humans, a herd of Adams and Eves kept in a state of innocence, cordoned off from contaminating knowledge (Snyder 2011, p. 475). Various features have been consciously removed from, or added to, the human genome, in a cut-and-paste fashion, resulting in an ersatz humanity: a community of peaceful vegetarians, 
eating their own caecotrophs to add vitamins to their $\operatorname{diet}^{9}$; post-humans who are no longer tormented by sexual cravings or aggression. ${ }^{10}$

As an archaeologist of the pre-apocalyptic future, Snowman guides the readers through the cataclysmic aftermath, tainted by ersatz food remains. During one of his expeditions, he breaks into a house:

"He hopes he'll find some canned food there, soy stew or beans and faked wieners, anything with protein in it - even some vegetables would be nice, ersatz or not, he'll take anything - there's a handful of dry cereal, so he eats that; it's unadulterated junk-gene cardboard and he has to chew it... There's also a tin of SoyOBoy sardines" (232/3).

Subsequently, he forces his way into a former Compound watchtower, a "minioasis". Here again, we find him rummaging through the kitchen cupboards:

"Real chocolate. A jar of instant coffee, ditto coffee whitener, ditto sugar. Shrimp paste for spreading on crackers, ersatz but edible. Cheese food in a tube, ditto mayo. Noodle soup with vegetables, chicken flavour. Crackers in a plastic snap-top. A stash of Joltbars. What a bonanza" (p. 272)

The find entrances him.

Finally, he reaches 'Paradice Dome', erstwhile headquarters of mastermind Crake: a return to the traumatic primal crime scene, the story's ground zero, where Crake's experiments were initiated and the Crakers were originally kept. In this most uncanny, unhomely place, Snowman finds frozen edibles, ChickieNobs Gourmet Dinners, caramel soycorn and a tin of SoyOBoy fake wieners.

In other words, Jimmy/Snowman scavenges and ruminates in a "foodscape" that reveals contemporary civilisation's fixation on surrogacies and replacements. An ersatz world had been created to address humanity's relentlessly growing demand for food: biotechnology as a "perverse" response to the problem of dwindling resources (Hall 2009, p. 180). The pre-catastrophic future depicted in Oryx and Crake is not all that unfamiliar compared to the contemporary world. It is presented as a future we are already heading towards.

Take for instance the following scene, commemorating Jimmy's visit to Crake when the latter was still a very promising student in a high-ranking academic Institute called Watson-Crick:

Next they went to NeoAgriculturals. [Jimmy and Crake] had to put on biosuits before they entered the facility, and scrub their hands and wear nose-cone filters, because what they were about to see hadn't been bioform-proofed... They were looking at a large bulblike object that seemed to be covered with

\footnotetext{
9 "On his first visit they'd offered [Jimmy] a couple of handfuls of leaves and roots and grass, and several caecotrophs they'd kept especially for him. He finds the caecotrophs revolting, consisting as they do of semi-digested herbage, discharged through the anus and re-swallowed two or three times a week" (p. 158).

10 "Territoriality in them had been unwired. They ate nothing but leaves and grass and roots and a berry or two. Their sexuality was not a constant torment to them, not a cloud of turbulent hormones. They came into heat at regular intervals", thus mating according to "biologically programmed instincts rather than to erotically situated drives" (Hall 2009, p. 185).
} 
stippled whitish-yellow skin. Out of it came twenty thick fleshy tubes, and at the end of each tube another bulb was growing...

"Those are chickens," said Crake. "Chicken parts. Just the breasts..."

"But there aren't any heads," said Jimmy. He grasped the concept - he'd grown up with sus multiorganifer, after all- but this thing was going too far.

"That's the head in the middle," said the woman. "There's a mouth opening at the top, they dump the nutrients in there. No eyes or beak or anything. They don't need those."

"This is horrible," said Jimmy. The thing was a nightmare. It was like an animal-protein tuber." The woman explained that they'd removed all the brain functions that had nothing to do with digestion, assimilation and growth... This thing feels no pain" (202/203).

It is clear that what Jimmy is looking at are lab-produced ersatz chickens (cultured meat). Jimmy feels like a Cro-Magnon visiting the future, with its peculiar, manmade bioforms. He has the uncanny feeling that "Some line has been crossed, some boundary transgressed", but Crake sees it differently: "I don't believe in Nature, not with a capital N", he exclaims (p. 206).

This pre-apocalyptic commitment to 'ersatz' not only pertains to food, but also to other dimensions of human desire, notably sexuality and the death drive. Rather than developing intimate relationships, Crake and Jimmy spend countless hours watching pornography on the internet, which functions as an immense erotic supermarket. They visit sites of professional sex-skills experts, super-swallowers, trapeze artists (with spangles glued like fish scales onto their skin) and installation artists who record every moment of their life for "millions of voyeurs" (p. 84). In real life, Crake is not "sexually active" (p. 192), but regards love as a "hormonally induced delusional state" (p. 193), a waste of energy he prefers to spend on his life goal as a bioengineer. The Watson-Crick Institute routinely employs erotic trafficking referred to as "student services" (208), involving sex workers and trained professionals recruited from the pleeblands, a system that "avoids the diversion of energies into unproductive channels, and short-circuits malaise ... you can get any body type... They provide everything" (p. 208). In short: erotic consumerism.

At a certain point, an intimate relationship evolves between Crake and a young woman named Oryx, a former child actress from the East-Asian porn movie industry (referred to as "Pixieland"). Crake employs her as guardian/caretaker of the Crakers (the neo-humans), teaching them what to eat and what not to eat. But she performs other services as well. Crake and Jimmy first discovered her on the internet as a naked, "small-boned, exquisite little girl" (p. 90), licking whipped cream from a giant male body with her "kittenish tongue" (90), until she looks right into the eyes of the viewer, so that roles are suddenly reversed. Being seen instead of seeing, Jimmy feels "hooked by the gills" (p. 91). But it remains dubious whether Oryx really is the adult version of this exploited little girl. 
A relationship between her and Jimmy evolves, but from the beginning it seems a "service" or "transaction" arranged by Crake. She is sent to him when the latter has more important things on his mind ("Crake never wants sex when he's thinking", p. 319). She is consistently depicted as an 'edible' woman: licking her hands (126), comparing herself to fruits, or spraying herself with a citrus-derived chemical compound. She is a ready-at-hand, erotic 'consumable', a phantasy object come to life (Hall 2009, p. 180). Much to Jimmy's regret, she refuses to see her life inside Paradice Dome as a discontinuation from her previous existence of exploitation.

The ideology of 'ersatz' also permeates the realm of the death drive, which is satisfied by playing violent computer games, endlessly and repetitiously, such as Barbarian Stomp, involving 'civilisations against hordes'. Top of the list is Extintathon, a game involving living and extinct species. Crake and Jimmy spent many hours playing it, but they also surf the net to watch surgical operations, calamities, political assassinations and executions (although it is often difficult to tell whether these are fake or real).

Crake the bioengineer develops a super-pharmaceutical: the BlyssPlus pill, offering an unlimited supply of libido and sexual prowess while protecting the user against sexually transmitted diseases. And it also acts as a birth control pill, moreover. Basically, the pill sterilises humanity while providing "endless highgrade sex". Inside this pill, the lethal virus is hidden: the object $a$ of biotechnological research, his masterpiece, comparable in many ways to the engineered virus in Dan Brown's Inferno (2013): a high-tech art-work, something in-between living and non-living, natural and artificial, beneficial or disastrous. As such, it is the $\varphi \alpha \rho \mu \alpha \kappa o n$, the cure (designed to relieve humanity of its malaise, Cooke 2006, p. 72) that is at the same time a deadly poison. On television, Jimmy follows the disastrous events. Channel after channel goes dead, until Homo sapiens sapiens joins the already extinct polar bear, and there is nothing more to watch.

After the global cleansing (Cooke 2006), Jimmy is the sole survivor, as we have seen. He convinces the neo-humans to bring him a fish once a week to eat ("too paltry and tasteless to have been exterminated", p. 100). They accept Snowman's "monstrousness", his "beastly appetites", but keep their distance and avert their eyes while Jimmy "crams handfuls of fishiness into his mouth" (p. 101): a spectacle of depravity, an atavistic reminder of a vanished world.

While sexuality and aggression are 'domesticated' with the help of the internet, the public sphere is ravaged by violent conflicts over food. Jimmy's earliest childhood memory involves a bonfire: a pile of infected cows and sheep and pigs (p. 15). There is the hint that the livestock pandemic was brought about via an airborne 'bioform' made by bioterrorists who opposed the bio-industry ("They say it was brought in on purpose... we've got the bioprint", p. 19).

Jimmy's father is a "genographer" working for OrganInc Farms, mapping the proteome, one of the architects of the Pigoon project, splicing and adding a rapidmaturity gene, so that kidneys, livers and hearts can grow faster and new organs can replace the procured ones. It is claimed that "none of the defunct pigoons (containing human stem cells) end up as bacon and sausages" (p. 23), but "as time went on and the permafrost melted and the vast tundra bubbled with methane and 
the Asian steppes turned to sand dunes, some people had their doubts: Pigoon pie again".

Jimmy's mother had been opposed to the whole project, depicting it as a moral cesspool. She regarded this interfering with the building blocks of life as "immoral" and "sacrilegious" (p. 57), but disappears one day and is eventually captured and executed as a bioterrorist: allegedly a member of an organisation that produces hostile bioforms such as vicious Ebola or Marburg splices, a "taint" on Jimmy's correctness file (p. 182).

At a certain point, a "war" breaks out over the Happicuppa coffee bean, designed to grown on huge plantations, where it can be harvested with machines, reducing small growers to poverty. The resistance movement is global. Riots erupt, crops are burned, Happicuppa personnel is car-bombed or shot by snipers, while on the other side hundreds of peasants and protesters are massacred by a private security organisation named CorpSeCorps.

As a student, Jimmy shares a dorm with a fundamentalist vegan who steals his leather sandals to incinerate them. Later, he befriends a bio-artist named Amanda, whose artworks involve truckloads of large dead-animal parts arranged in the shape of words. She shares a condo with two other artists. When they spot Jimmy eating a ChickieNobs Bucket O'Nubbins, they subject him to a long sermon about how, beginning with the invention of agriculture, the human experiment was doomed from the very outset (p. 242), driving countless species into extinction: "Human society, they claimed, was a sort of monster, like a giant slug eating its way relentlessly through all the other bioforms on the planet, grinding up life on earth and shitting it out in the form of plastic junk" (p. 243).

The pre-apocalyptic Compounds represent the highest stage of an ersatz producing world which is suddenly wiped out by a spliced and lethal bioform. Its food products are as dissatisfying and nauseating as its internet pornography and its violent computer games. A food civilisation that steers too close towards the 'sun' of high technology is bound to crash, that is the morale of the story. One day we will find ourselves stranded on a sunburned beach, littered by ersatz waste. This message is nicely conveyed by a (misspelled, German) slogan, a prophetic summons almost, printed on one of the fridge magnets cited in the novel: Du musst dein Leben ändern (p. 301): better your life, before it is too late. Ultimately, what is rejected is the phantasmatic idea that high-tech food items can be our untainted, salvaging object $a$, able to take away our discontent.

\section{Concluding Remarks}

Psychoanalysis tends to pay more attention to sexuality than to food intake. In terms of biological life goals, the focus has always been on pairing and reproduction rather than on care and survival. And yet, as I have argued, psychoanalytic theory does provide important insights for understanding alimentary discontent. The question now is whether, besides supplying us with analytic tools for self-analysis, some 'therapies' may be suggested as well. Foucault (1976) has argued that, in the sexual realm, psychoanalysis offers a scientia sexualis rather than an erotica, and this 
seems to apply to the psychoanalysis of food as well. It entails a (psychological) scientia nutritionalis rather than a (moral) ars consumptio. In other words, whereas its theoretical value for understanding contemporary alimentary predicaments seems significant, its value for a practical improvement of food habits and consumer morality seems less obvious.

Psychoanalysis suffers from what has been referred to as 'therapeutic nihilism'. The emphasis is on diagnosis (or even: 'interminable analysis') rather than on betterment. In other words, Freud and Lacan agree that alimentary discontent will never go away. The gap between what we seek and what we find will never be bridged. Instead of answering consumer questions, these are contextualised and analysed from an oblique perspective, bent on elucidation rather than on problemsolving, and on clarifying the causes of consumer malaise rather than on producing policy guidelines.

Nonetheless, some provisional precepts for dealing with the malaise can be provided. First of all, consumers are urged to opt for the reality principle. The discovery of the alimentary object $a$ will prove a transitory experience at best, as we have seen. And yet, in the folds and margins of the global food production system, consumers may develop an alimentary niche/enact a consumer identity of their own, establishing their own 'midden' as it were: 'this is who I am', 'this is where I stand'. On the collective level, the reality principle basically comes down to an ethic of sobriety and moderation, opting for a more sustainable, less addictive life-style, avoiding anorectic and obese extremes, but in combination with the stoic awareness that, in the case of humans, since time immemorial, food production and consumption have always entailed elements of estrangement and crisis.

Open Access This article is distributed under the terms of the Creative Commons Attribution License which permits any use, distribution, and reproduction in any medium, provided the original author(s) and the source are credited.

\section{References}

Atkinson, L. (2013). Clarifying, confusing or crooked? Interpretations of green advertising claims by ethically minded consumers. In M. Drumwright \& S. Reese (Eds.), Ethical issues in communication professions: New agendas in communication. London: Routledge.

Atwood, M. (2003). Oryx and Crake. New York: Doubleday.

Brown, D. (2013). Inferno. New York: Doubleday.

Cooke, G. (2006). Technics and the human at zero-hour: Margaret Atwood's Oryx and Crake. Studies in Canadian Literature, 31(2), 63-83.

Fernández-Armesto, F. (2002). Near a thousand tables: A history of food. New York: Free Press.

Foucault, M. (1976). Histoire de la sexualité 1: La volonté du savoir. Paris: Gallimard.

Fresco, L. (2012). Hamburgers in het Paradijs [Hamburgers in Paradise]. Amsterdam: Prometheus/Bert Bakker.

Freud, S. (1892/1952). "Ein Fall von hypnotischer Heilung”. Gesammelte Werke I. London: Imago, 3-17.

Freud, S. (1895/1952). “Studien über Hysterie”. Gesammelte Werke I. London: Imago, 75-312.

Freud, S. (1905/1942). "Bruchstück einer Hysterie-Analyse". Gesammelte Werke I. London: Imago, 75-312, 161-286.

Freud, S. (1913/1940). Totem und Tabu. Gesammelte Werke IX. London.

Freud, S. (1919/1947). “Das Unheimliche”. Gesammelte Werke XII. London: Imago, 227-268.

Freud, S. (1930/1948). Das Unbehagen in der Kultur. Gesammelte Werke XIV. London: Imago, 419-513. 
Galbreath, M. (2010). A Consuming Read: the Ethics of Food in Margaret Atwood's Oryx and Crake. Presented at: Florida Gulf Coast University's 2nd International Humanities and Sustainability Conference, Fort Myers, Florida.

Hall, S. (2009). The last laugh: A critique of the object economy in Margaret Atwood's Oryx and Crake. Contemporary Woman's Writing, 4(3), 179-196.

Hambuch, D. (2013). Speculative writing and environmentalist politics. Ecocritical readings of Oryx and Crake and Der Schwarm. Arab World English Journal, 1, 42-54.

Hegel, G.W.F. (1807/1970/1986). Phänomenologie des Geistes. Frankfurt am Main: Suhrkamp.

Hopkins, P. D., \& Dacey, A. (2008). Vegetarian meat: could technology save animals and satisfy meat eaters? Journal of Agricultural and Environmental Ethics, 21(6), 579-596.

Korthals, M. (2010). Before dinner. Philosophy and ethics of food. Dordrecht: Springer.

Lacan, J. (1965/1966). Le séminaire XIII: L'objet de la psychanalyse. [Not formally published as yet].

Lacan, J. (1973). Le séminaire XI: Les quatre concepts fondamentaux de la psychanalyse. Paris: Éditions du Seuil.

Lacan, J. (1981). Le séminaire III: Les psychoses. Paris: Éditions du Seuil.

Lacan, J. (1986). Le séminaire VII: L'éthique de la psychanalyse. Paris: Éditions du Seuil.

Morton, T. (2007). Ecology without nature: Rethinking environmental aesthetics. Cambridge: Harvard University Press.

Sahlins, M. (1968). Notes on the Original affluent society. In R. B. Lee \& I. DeVore (Eds.), Man the hunter (pp. 85-89). New York: Aldine Publishing Company.

Sahlins, M. (1972). Stone age economics. London: Transaction Publishers.

Schroeder, J. L. (2004). The triumph of venus: The erotics of the market. Ewing: University of California Press.

Selvini-Palozzoli, M. (1985). Anorexia nervosa: A syndrome of the affluent society. Transcultural Psychiatric Research Review, 22, 199-205.

Sinclair, U. (1905/1906). The Jungle. New York: Grosset \& Dunlap.

Snyder K. (2011) 'Time to go': The post-apocalyptic and the post-traumatic in Margaret Atwood's Oryx and Crake. Studies in the Novel, 43(4), 470-489.

van der Weele, C., \& Driessen, C. P. G. (2013). Emerging profiles for cultured meat; ethics through and as design. Animals, 3(3), 647-662.

van der Weele, C., \& Tramper, J. (2014). Cultured meat: every village its own factory? Trends in Biotechnology, 32(6), 294-296.

Zwart, H. (2000). A short history of food ethics. Journal of Agricultural and Environmental Ethics, 12, $113-126$.

Zwart, H. (2005). Food consumption in the genomics era: A foucauldian perspective. Tailoring Biotechnologies, 1(2), 31-44.

Zwart, H. (2009). Biotechnology and naturalness in the genomics era: Plotting a timetable for the biotechnology debate. Journal of Agricultural and Environmental Ethics, 22, 505-529.

Zwart, H. (2014). The elephant, the mirror and the Ark. Rereading Lacan's animal philosophy in an era of ontological violence and mass extinction. Journal of Critical Animal Studies, 12(1), 1-32.

Zwart, H., \& Penders, B. (2011). Genomics and the Ark. An ecocentric perspective on human history. Perspectives in Biology and Medicine, 54(2), 217-231. 